\title{
Methane Gas Reduction Using Virgin Coconut Oil Supplementation in Rumen Fermentation through in Vitro
}

\author{
Erwin Hubert Barton Sondakh"), Johnly Alfreds Rorong ${ }^{2)}$, Jerry Audy Donny Kalele ${ }^{1)}$ \\ 1)Faculty of Animal Science, University of Sam Ratulangi, Manado 95115 Indonesia \\ 2) Faculty of Math and Science, University of Sam Ratulangi, Manado 95115 Indonesia \\ Corresponding author email: erwin_sondakh@yahoo.com
}

\begin{abstract}
This study aims to determine the effect of virgin coconut oil (VCO)supplementation in ruminant feed on the methane reduction in vitro. The study used rumen fluid with forage substrate and concentrates in the ratio of 60:40. The experiement consists of five kinds of VCO treatments, namely: RO - feed substrates without VCO; R1 - feed substrates with $2 \%$ VCO; R2 - feed substrates with $4 \%$ VCO; R3 - feed substrates with $6 \%$ VCO; and R4 - feed substrates with $8 \%$ VCO. Each treatment was done three times. The fermentation used Hohenheim Gas Test (HGT) at $39^{\circ} \mathrm{C}$ for 48 hours. At the end of fermentation, measurements of methane and microbial activity of the rumen fluid were implemented. Data obtained were analyzed using a completely randomized design, and continued with Duncan test for examining the mean differences. The results showed that methane production descreased by $18.39 \%-29.7 \%$ when the feed was given $2 \%-8 \%$ VCO. Based in the findings, it can be concluded that the supplementation of $2 \%-8 \%$ VCO can be used a substrate for ruminant feed because it can reduce methane and does not interfere the microbial activity of the fermentation of rumen fluid through in vitro.
\end{abstract}

Key words: methane reduction, virgin coconut oil, rumen fermentation, ruminant, in vitro

Abstrak. Penelitian ini bertujuan untuk mengetahui pengaruh suplementasi virgin coconut oil (VCO) pada pakan ruminansia terhadap reduksi metan secara in vitro. Penelitian ini menggunakan cairan rumen dengan substrat hijauan dan konsentrat dengan perbandingan 60:40. Percobaan ini terdiri dari lima macam perlakuan VCO yakni: R0: substrat pakan tanpa VCO; R1: substrat pakan dengan VCO 2\%; R2: substrat pakan dengan VCO 4\%; R3: Substrat pakan dengan VCO 6\% dan R4 substrat pakan dengan 8\% VCO. Setiap perlakuan dilakukan tiga kali ulangan. Fermentasi dilakukan menggunakan Hohenheim Gas Test (HGT) pada suhu $39^{\circ} \mathrm{C}$ selama 48 jam. Pada akhir fermentasi dilakukan pengukuran gas metan dan aktivitas mikrobia cairan rumen. Data dianalisa menggunakan rancangan acak lengkap dan dilanjutkan dengan Duncan test untuk perbedaan rataan. Hasil penelitian menunjukan bahwa produksi metan mengalami penurunan sekitar 18,39\%-29,7\% ketika pakan diberi VCO sebanyak 2-8\%. Dari hasil penelitian disimpulkan bahwa suplementasi VCO 2-8\% dapat digunakan sebagai substrat pakan ruminansia karena dapat mereduksi gas metan serta tidak mengganggu aktivitas mikrobia pada fermentasi cairan rumen secara in vitro.

Kata kunci: reduksi metan, virgin coconut oil, fermentasi rumen, ruminansia, in vitro

\section{Introduction}

The Government of Indonesia is currently mobilizing a policy of self-sufficiency in meat, which has managed to improve the population of beef cattle to nearly 14.3 million, with a growth rate of $2.7 \%$ annually and meat production of 420.4 thousand tons per year, with an average growth of $7.92 \%$ annually until 2014. However, despite the effort to increase the production of meat and the awareness of the community on the importance of livestock products as the sources of protein, there is a global issue that positions farms as the biggest emitters/producers of methane in the atmosphere, which has been associated with the destruction of ozone and global warming.

It is inevitable according to Steinfeld et al. (2006) that the farming sector accounts for the largest gas emissions, up to $35 \%$. Such statement places the farming sector in a problematic position; thus, it should be reconsidered wisely, given that the consumption of livestock products in Indonesia 
is still low and the growth of farming is slow, while the products are much needed by the community. Therefore, conflicts of interests should be resolved. Such a circumstance becomes the underlying reason of this research, which focuses on the reduction of methane in ruminant livestock; it is expected that the rate of methane emissions in the atmosphere can be suppressed.

Methane is one of the products of the fermentation of livestock feed by rumen microbes. Protozoa metabolic activities are related to the formation of methane in the rumen (Dohmeet et al., 1999). Methanogenic bacteria attach themselves to the ciliate protozoa to get a constant supply of hydrogen (Kamra, 2005). Thus, the formation of methane occurs because the protozoa binds hydrogen and transfers it to methanogens.

The role of fat dietary in reducing the formation of methane is needed. Machmuller (2006) found that medium chain fatty acids (MCFA) can suppress the activity of methanogenic bacteria through the inhibition of protozoa. Virgin coconut oil (VCO) is feed containing MCFA derived from coconut oil processing waste, which can be easily obtained. The MCFA can be used as a feed supplement that can serve as a defaunation agent of protozoa; it can reduce methane production in the ruminant digestive system, which in turn will prevent methane gas accumulating in the atmosphere, deriving from farms.

\section{Materials and Method}

The material used was rumen fluid as the source of microorganism derived from mature ruminants. VCO was taken from a VCO manufacturing plant. The substrate was made of elephant grass, and the concentrate ratio was 60:40. In vitro testing solutions were fermenters, syringe, and waterbath.

This research was conducted using a completely randomized design (Steel and
Torrie, 1991). The experiment employed the following VCO supplementations: R1 - 0\% VCO; R2 - 2\% VCO; R3 - 4\% VCO; R4 - 6\% VCO; and R5 $8 \%$ VCO in dry matter. The variables measured were production of methane (Menke and Steingass, 1988), volatile fatty acids (VFA)(Menke and Steingass, 1988), and the number of protozoa (Diaz et al., 1993).

\section{Research procedure.}

Each treatment was put in the syringe for in vitro test with a closed system of anaerobic fermentation at $39^{\circ} \mathrm{C}$ for 48 hours (Yusiati, 1996). Through experimental gas tests, the gas was taken from the syringe using a spuit and inserted into Venoject ${ }^{(R)}$ for analyzing the formed gas. The fermented liquid was filtered to separate the feed material which was not degraded and centrifuged at $3.000 \mathrm{~g}$ for 15 minutes to separate the supernatant from the particles of the feed material which had not been separated during the filtering. Further, the supernatant was taken and centrifuged at $10.000 \mathrm{~g}$ for 15 minutes to separate the supernatant from microbial sediment. Then, the supernatant was taken to measure the protozoa (Diaz et al., 1993), total VFA with HPLC method.

\section{Results and Discussion}

\section{Number of protozoa}

The results indicate that there are different numbers of protozoa $(P<0.05)$ in feed given VCO and feed without VCO in rumen fermentation through in vitro. The supplementation of VCO up to $4 \%$ has not led to different numbers of protozoa. The decrease of protozoa occured when the supplementation was $6-8 \%$. The number of protozoa tends to decrease along with the increase of VCO in the feed.

VCO which has much medium chain fatty acids (MCFA) is seen as the cause of the decline of the number of protozoa. This is because the VCO contains lauric acid (MCFA), which is toxic to ciliated protozoa. 
Table 1. The mean of methane production, protozoa population, volatile fatty acids (VFA) in thefermentation of feed with various VCO levels by rumen microbes through in vitro

\begin{tabular}{|c|c|c|c|c|c|}
\hline & \multicolumn{5}{|c|}{ Treatments } \\
\hline & RO & R1 & $\mathrm{R} 2$ & R3 & R4 \\
\hline Number of Protozoa (cell / ml) & $8098.96^{b}$ & $7682.29^{b}$ & $6484.38^{b}$ & $5625.00^{a}$ & $5546.88^{a}$ \\
\hline $\begin{array}{l}\text { Methane Gas } \\
\text { (ml / g DDM / } 48 \text { hours) }\end{array}$ & $12.45^{b}$ & $10.16^{\mathrm{a}}$ & $9.18^{\mathrm{a}}$ & $8.96^{a}$ & $8.74^{\mathrm{a}}$ \\
\hline VFA (mMol) & & & & & \\
\hline Acetate $^{\mathrm{ns}}$ & 5.81 & 5.95 & $5: 29$ & $5: 43$ & 5:06 \\
\hline Propionate & $1.58^{\mathrm{a}}$ & $1.66^{\mathrm{a}}$ & $1.89^{b}$ & $1.94^{b}$ & $1.96^{\mathrm{b}}$ \\
\hline Butyric $^{\text {ns }}$ & 0.53 & 0.51 & 0.50 & 0.48 & 0.45 \\
\hline $\begin{array}{l}\text { Microbial Protein } \\
(\mathrm{mg} / \mathrm{ml})^{\mathrm{ns}}\end{array}$ & 0.26 & 0.27 & 0.27 & 0.24 & 0.26 \\
\hline $\mathrm{NH}_{3}(\mathrm{mg} / 100 \mathrm{ml})^{\mathrm{ns}}$ & 24.49 & 27.81 & 27.52 & 26.16 & 24.84 \\
\hline
\end{tabular}

According stated Machmuller (2006), MCFA is the most powerful anti-protozoal which inhibits the growth and activity of ciliate protozoa (entodinium spp). Furthermore, Machmuller states that lauric acid can increase the microbial sensitivity on cell walls, thus inhibiting ciliate protozoa and archaea positive gram. This is in line with the findings of Sondakh et al. (2012), that the addition of MCFA of $1-1.5 \%$ can reduce the amount of protozoa $-29.84 \%$ in rumen fluid fermentation through in vitro. Similarly, Sitoresmi et al. (2009) show that supplementation until 5\% causes the decrease the number of protozoa up to $23.95 \%$.

\section{Methane production}

The results show that the supplementation of VCO in the feed has an effect on the formation of methane gas $(P<0.05)$. The supplementation of $2 \%-8 \%$ of VCO caused the decrease of methane in rumen fermentation in vitro. The supplementation of $2 \%-8 \%$ has not led to differences of the production of methane. Therefore, the results indicate that $2 \%$ MCFA on the feed is adequate for reducing methane by $18.39 \%$.
The decrease of methane is suspected due to the influence of the VCO. As shown in Table 1 , VCO functioned as a defaunation agent which could inhibit the activity of protozoa. This is in line with the parameters of numbers of protozoa being examined, which also decreased. The potential of VCO as an agent of defaunation may be because VCO contains medium chain fatty acids. The research of Karouw et al. (2012) indicates that VCO contains $54 \%$ of medium chain fatty acid. The fatty acid is the material inhibiting the activity of protozoa. According to Hristov et al. (2004), MCFA is a fatty acid that is toxic to ciliated protozoa. It was shown that there was a decrease of the production of methane when the feed was given MCFA. The decrease of MCFA is closely associated with the presence of protozoa in the rumen. Hegarty (1999) states that the protozoa is an agent that serves as a unifier of methanogenic and its ciliate in symbiosis, causing the formation of methane. The decline of protozoa disrupts the symbiosis of ciliateprotozoa and methanogenic, resulting in the insufficient methane formation. This is supported by the research of Sondakh et al. (2012) which shows that the supplementation 
of $1 \%-1.5 \%$ MCFA can decrease the production of methane up to $25.30 \%$.

\section{Volatile Fatty Acid (VFA)}

The content of VCO up to $8 \%$ in the given feed substrate does not give a significant effect on the acetate and butyrate from the fermentation of rumen microbes in vitro,yet, it shows a significant effect on propionate ( $P$ $<0.05)$. The supplementation of VCO causes the difference in the propionate profile average. The difference is closely related to the use of VCO in the substrate of feed. In the supplementation of $4 \% \mathrm{VCO}$, there is an increase of propionate compared to the substrate of feed which was not given VCO. Meanwhile, $4 \%-8 \%$ VCO in the substrate of feed does not cause a difference of the number of propionate profiles. Sondakh et al. (2012) state that the amount of propionic acid depends on the production of methane, when methane is reduced, there will be an increase in the amount of propionate. Similarly, Wei-lian et al. (2005) state that the process of defaunation results in the decrease of the VFA concentrate; however, the propionate molar increases. The increase of propionate is predicted to be related to the decrease of the production of methane in rumen fermentation.

Acetic and butyric acids in the feed given VCO up to $8 \%$ have not led to changes in the content of the volatile acids; the total VFA was similar. The results of molar ratios of acetate and propionate for feed fermentation ranged from 2.58 to 3.58. According to Hungate et al. (1975), in normal conditions, the molar ratio of acetate and propionate is 3.125. According to Yusiati et al. (2008) and Sitoresmi et al. (2009), the VFA level depends on the provision of substrate types and proportions, as well as the difference of addition of the types and forms of fatty acids.

\section{Microbial protein synthesis}

The effect of the supplementation of VCO with different levels on the microbial protein synthesis through in vitro can be seen on Table 3. The results show that the supplementation of VCO up to $8 \%$ in rumen fermentation through in vitro does not affect the microbial protein synthesis. The supplementation of $8 \% \mathrm{VCO}$ to substrate forages and concentrates with a $60: 40$ ratio is in the range of 0.24 to $0.27 \mathrm{mg} / \mathrm{ml}$. This research is aligns with the study of Sitoresmi (2008) which suggests that the supplementation of coconut oil up to $7.5 \%$ does not significantly affect microbial protein synthesis; the range of microbial protein is from 0.38 to $0.39 \mathrm{mg} / \mathrm{ml}$.

The results of this study are still far below the results of microbial protein synthesis by Yusiati et al. (2008), which indicates that the supplementation of lemuru fish oil up to $7.5 \%$ DM in the fermentation of king grass and fine bran with a ratio of 80:20 through in vitro has a range of 0.51 to 0.56 . Orskov (1992) states that the precursor for the synthesis of microbial protein depends on the availability of sufficient carbon skeleton, $\mathrm{NH}_{3}$ and energy.

\section{$\mathrm{NH}_{3}$}

The effect of the supplementation of different levels of $\mathrm{VCO}$ on $\mathrm{NH}_{3}$ throughin vitro can be seen in Table 3. The results show that the supplementation of VCO up to $8 \%$ in rumen fermentation through in vitro does not affect the $\mathrm{NH}_{3}$.The supplementation of $8 \% \mathrm{VCO}$ to the substrate forages and concentrates with a $60: 40$ ratio, $\mathrm{NH}_{3}$ is in the range of 24.49 to $27.81 \mathrm{mg} / 100 \mathrm{ml}$. The results of this study are still far below the results of research by Sitoresmi et al. (2009), which indicate that the level of ammonia (NH3) with supplementation of oil up to $7.5 \%$ is in the range of 33.24 to $34.53 \mathrm{mg} / 100 \mathrm{ml}$.

Mc Donald et al. (1988) reported that the concentrations of NH3 vary greatly, depending on the degradation of feed. Hungate (1996) states that the over-production of NH3 is not beneficial for the formation of microbial protein; it will just be wasted. 


\section{Conclusions}

Based on the results of the study, it can be concluded that the supplementation of VCO up to $2 \%-8 \%$ can be used as a substrate of ruminant feed, because it can reduce methane and does not interfere the microbial activity in the fermentation of rumen fluid through in vitro.

\section{Acknowledgement}

We express our gratitude to Sam Ratulangi University for funding the research in project of RUU 2015.

\section{References}

Diaz, A, M Avendano, and A Escobar. 1993. Evaluation of Sapindus saponaria as a Defaunating Agent and Its Effects on Different Ruminal Digestion Parameters. Livestock Research for Rural Development. Vol 5(2). http://www.Irrd.org/Irrd5/2/cefe.htm

Dohme, F, A Machmuller, BL Esterman, P Pfister, A Wasserfallen, and M Kreuzer. 1999. The Rule of the rumen protozoa for methane suppression caused by coconut oil. Letter in Applied Microbiology 29:187-192.

Halliwel, G, NNBA Wahab, and AH Patle. 1985. Chemical composition of Endo1,4 - $\beta$-glucanase to cellulotic in trichoderma coningii. J. App. Biochemistry. 7:43-45.

Hegarty, RS. 1999. Reducing rumen methane emissions through elimination of rumen protozoa. Aust J. Agric. Res. 50: 1321 - 1328.

Hristov, AN, M Ivan and TA McAllister. 2004. In vitro effects on individual fatty acids on protozoal numbers and on fermentation products in ruminal fluid from cattle fed a high concentrate, barley-based diet. J. Anim. Sci. 82: 2693 - 2704.

Kamra, DN. 2005. Rumen microbial ecosystem. Special edition. Microbial Diversity. Current Sci. 89:124-135.

Karouw, S, C Indrawanto dan ML Kapu'allo. 2012. Karakteristik Virgin Coconut oil dengan metode sentrifugasi pada dua tipe kelapa. Buletin Palma Vol 15(2):128-133.

Machmuller, A. 2006. Medium-chain fatty acids and their potensial to reduce methanogenesis in domestic ruminants. Agri. Ecosyst. Environ. 112:107-114.

McDonald P, PA Edwards and JFD Greenhalg. 1988. Animal Nutrition. $4^{\text {th }}$ ed. Longman Sci. and Tech. New York.

Orskov ER. 1992. Protein Nutrition Ruminants. $2^{\text {nd }} e d$. Academic Press Limited, London.

Sitoresmi, PD, LM Yusiati and H Hartadi. 2009. Pengaruh penambahan minyak kelapa, minyak biji matahari, dan minyak kelapa sawit terhadap penurunan produksi metan di dalam rumen secara in vitro. Bulletin Peternakan. 33(2):96-105.

Sondakh EHB, LM Yusiati, H Hartadi, and E Suryanto. 2012. Bungkil kelapa sumber medium chain fatty acids dalam pakan ruminansia sebagai agensia penurun gas metan pada fermentasi rumen secara in vitro. Agrinimal. 2(2):39-43

Steinsfeld H, P Gerber, T Wassenaar, V Castel, M Rosales and C deHaan. 2006. Livestock's Long Shadow. Food and Agriculture Organisation of The United Nation. Rome.

Wei-lian, H, YM Wu, JX Liu, YQ Guo and JA Ye. 2005. Tea saponins affect in vitro fermentation and methanogenesis in faunated and defaunated rumen fluid. J. Zhejiang Univ. Sci. 6B:787-792.

Yusiati LM. 1996. Teknik Produksi Gas. Dalam:Kursus singkat teknik evaluasi pakan ruminansia. Fakultas Peternakan Universitas Gadjah Mada, Yogyakarta.

Yusiati LM, Z Bachrudin, C Hanim and E Lestari. 2008. The effect sardine (Sardinelle longiceps) oil as a sources of methanogenesis inhibitor agent on the rumen fermentation product of the diet containing different level of forages. In: Management Strategy of Animal Health and Production Control on Anticipation Global Warming for Achievment of Millenium Development Goals. Faculty of Veterinary Medicine Airlangga University. ISBN 978-97917677-1-2.

Zhu, WY, MF Iqbal, YF Cheng, JX Liu and SY Mao. 2008. Rumen methanogenesis and nutritional approaches to the mitigation of ruminant methane. Asian Australian J. of Animal Sciences.13:33-40. 